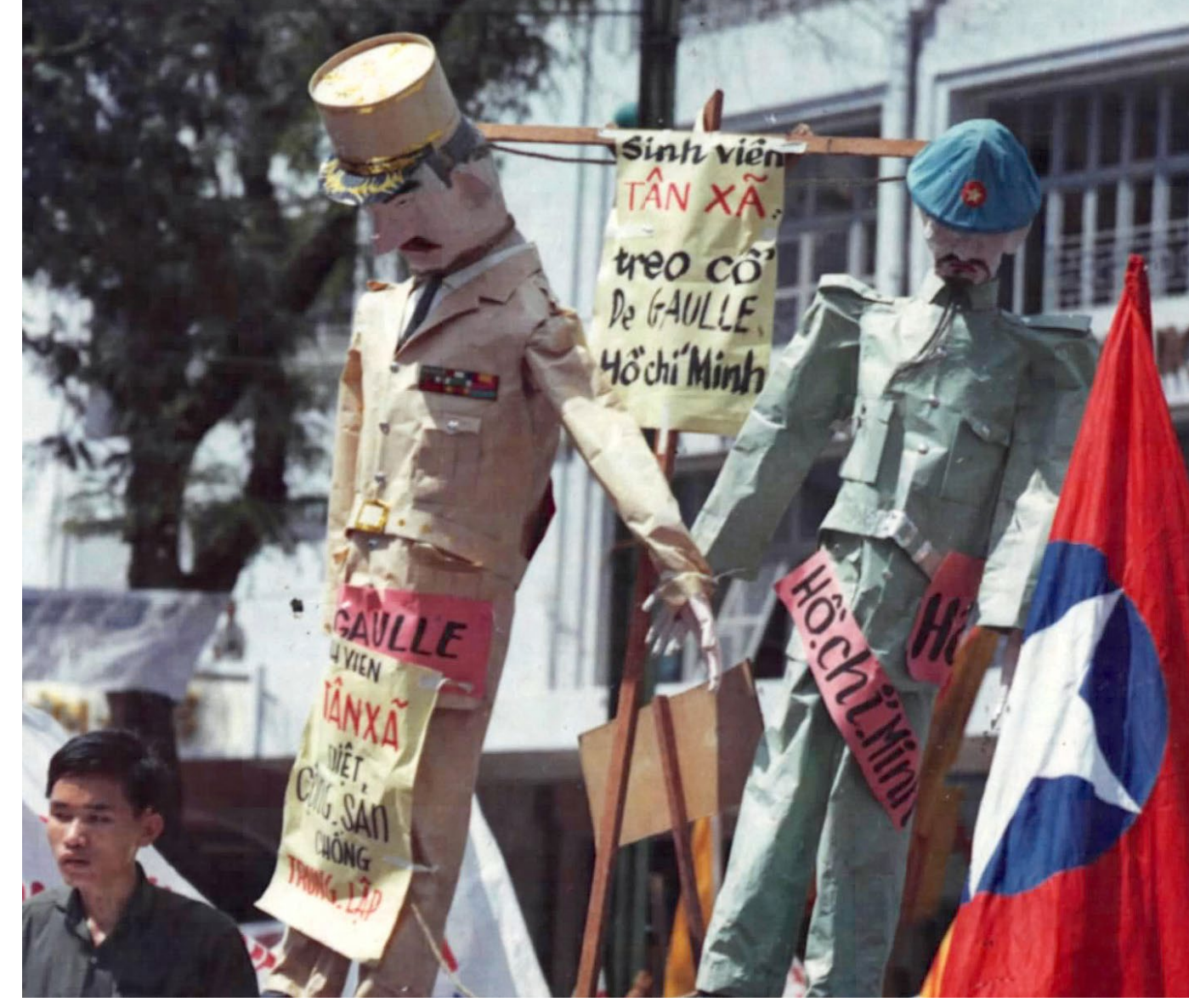

\title{
Willful Blindness: Franco-American Relations and Escalation of the Vietnam War
}

Olivier Bergeron-Boutin edited by Hannah Drinkell and Liz Wagner 
Cover art: Charles DeGaulle and Ho Chi Minh.

Source: United States Army [Public domain], via Wikimedia Commons.

This article was submitted to HIST 438: Topics in Cold War History.

\section{Abstract}

The long and stable Franco-American diplomatic rapport was undermined throughout the American escalation of the Vietnam War. This paper specifically examines French President Charles de Gaulle's increasing discontent at his ally's involvement in Southeast Asia and analyzes the decisions of successive American presidents to ignore him. Beginning in 1961, with the inauguration of American President John F. Kennedy, the paper proceeds chronologically to 1964, by which point transatlantic relations had worsened considerably as a result of de Gaulle's growing confrontation of the Indochina question. Using archival diplomatic documents from both countries, this paper seeks to explain why the United States government refused to comply with De Gaulle's requests. This papers makes two main conclusions: American policy makers were willfully blind to their ally's suggestions and the French proposal for the neutralization of Vietnam was not realistic. These findings are supported by various policy decisions made leading up to the war, relying heavily on primary sources to demonstrate the failings of both the French proposal and the American willingness to consider the perspective of a crucial ally.

\section{Introduction}

$\mathrm{O}$ n 29 August 1963, the French Minister of Information took the highly unusual step of publicizing President Charles de Gaulle's remarks at a Cabinet meeting earlier that day. After years of private misgivings, the general had finally elected to speak his mind: the future of Vietnam, he proclaimed, should be left for the Vietnamese people to decide. "Independence from exterior influences," Minister Peyrefitte quoted, could be achieved through a "national effort" leading up to reunification. An undivided Vietnam "would find France ready, to the extent of her own possibilities, to set up a cordial cooperation" (New York Times 1963).

Despite de Gaulle's refusal to make explicit reference to the United States, the August 29 pronouncement imbued a sense of Franco-American tension that seemingly threatened to destabilize the Western bloc's web of alliances. The declaration was a clear challenge to American policies in Southeast Asia, and it triggered a frantic public relations campaign by Kennedy administration officials to discredit the French proposal (Logevall 1992, 78-79). But to the intense displeasure of successive American presidents, de Gaulle was undeterred: as casualties mounted and progress stalled in Indochina, his public rebuke in
August 1963 would be followed by many others. Initially unclear, the French position evolved into a simple, yet controversial proposal: the neutralization of Vietnam through an international conference.

The strategic missteps that led to the fateful US involvement in a war some 13,000 kilometers away have been well documented (Logevall 1999). The existing historiography examining the role that France played-or sought to play-in American policy in Indochina is far less satisfying. De Gaulle's dissent, though lonely, resonated loudly in Washington's corridors of power: because of France's status as a crucial ally, American decision-makers could not afford to ignore the general's pleas. The French position, by virtue of its dissonance with the opinions of other Western leaders, can help refine our understanding of the American decision to escalate the conflict in Vietnam.

The purpose of this paper is to shed a novel light on the uneasy relations between France and the United States during the Cold War by examining the diplomatic tensions that resulted from the Vietnam War. The existing historiography examines Franco-American relations to some length but neglects one crucial aspect of the situation. From 1961 to 1964, as de Gaulle became increasingly assertive, it was still possible for the superpower to reverse course and withdraw from Southeast Asia. This begs the yet unanswered question: why did American policymakers not heed de Gaulle's advice on the subject of Vietnam?

After historians have exposed the flawed decisions that led to the Vietnam quagmire, it may seem patently clear that the de Gaulle's exhortations should have been considered carefully. Deepening involvement in Southeast Asia ultimately failed and weakened the American position in the Cold War (Gaddis $2005,267)$. But, as is often the case, the geopolitical reality was complex and riddled with uncertainty. From the American point of view, de Gaulle's intentions were muddled by his perceived "petty intransigence" and his desire to reassert France's role as an independent actor in international relations (Costigliola 1992). After consulting French and American primary sources, I have reached two main conclusions. First, American policymakers were obsessed with de Gaulle's motives for promoting an alternative strategy-so much so that they failed to consider seriously the substance of his proposals. Second, France's neutralization proposal was unrealistic given the Vietnamese and Chinese communists' steadfast commitment to a protracted revolutionary struggle. However, I will later argue that despite the "unworkable" French solution, the dissent from such an important ally should have compelled the Americans to a reconsider their approach.

\section{The Genesis of Gaullist Foreign Policy}

Charles de Gaulle's path to the 29 August 1963 declaration was remarkably 
tortuous. To any informed observer in the 1940s and early 1950s, the Frenchman would have appeared as an improbable proponent of Third World independence movements. After World War II, de Gaulle sought to reassert colonial control over Indochina and insisted that France would benefit from maintaining its empire. Warned by an Indochina specialist that this would prove to be impossible, de Gaulle replied: "Dear Professor, we will win because we are the strongest" (Goscha 2016, 228). Even as the situation in the Asian colony worsened, de Gaulle remained adamant. It is only with the disaster at Dien Bien Phu in 1954 that he grudgingly accepted France's defeat (Journoud 2011, 42-48).

But despite his unyielding attitude during the First Indochina War, the seeds of Gaullist thought regarding Third World nationalism had already been sown. The general viewed the nation as the defining feature of international affairs-as the irreplaceable unit of human organization. The nation, he believed, is permanent and it supersedes the conflict of ideologies (Costigliola 1994). In his memoirs, de Gaulle argues that "in the world's incessant movement, all doctrines, all schools, all rebellions, last only for a while. Communism will pass away. But France will not pass away" (De Gaulle 1954, 232). He felt that "in the long run, no regime can hold on against national wills"-a peculiar conviction for a man who had long supported the French colonial project (De Gaulle 1959, 47). The Algerian crisis would resolve this seeming incongruence between beliefs and actions. Following his return to power in May 1958, de Gaulle confronted a fierce independence movement in the North African colony. On 16 September 1959, after five years of resilient conflict, the president promised a "government of Algerians by Algerians, backed up by French help and in close relationship with her" (Byrne 2010, 67). The colonized, he stated, were entitled to selfdetermination. Though de Gaulle insisted that a close association between the two countries should continue, his outlook had evidently adapted to changing circumstances (Wall 2001, 92). France's failures in Algeria had convinced him that external powers were bound to fail in their attempts to suppress nationalist movements (Logevall 1992).

In conjunction with France's colonial misadventures, the country's purportedly unfavorable position in the post-war order left an indelible imprint on the president's worldview. The Republic had been humiliated by its surprisingly swift defeat at the hands of Germany in 1940, by its absence at the Yalta conference of Allied powers, and by the Suez crisis. De Gaulle, along with many of his fellow citizens, believed that his country had been unfairly ostracized from the great power club. He perceived the hegemonic power of the United States to be particularly threatening and argued that France needed strong, assertive statesmanship to restore its prestige and reassert its independence. The situation in Vietnam provided him with an excellent opportunity to show that France would not submit to American expectations (Bozo 2010).

\section{Rumblings of Discontent}

In the days following President John F. Kennedy inauguration on 20 January 1961, an aura of agitation emanated from the State Department's anxious bureaucracy: the challenges that the new administration faced, not the least of which the unpredictable behavior of Soviet Premier Nikita Khrushchev, were intimidating. One of the problems identified early on was France: a memorandum circulated to Secretary of State Dean Rusk singled out President de Gaulle as a potential troublemaker (Foreign Relations of the United States 1958, 223). To be certain, this was not an attitude singular to the incoming administration; as soon as the general had returned to power in 1958, President Dwight D. Eisenhower complained that he was becoming "increasingly troublesome" and concluded that the United States had to "watch out for him" (Foreign Relations of the United States 1958, 79). On the French side, as inauguration day approached, new instructions were sent out to Ambassador to the United States Hervé Alphand. In his message to Alphand, Foreign Minister Maurice Couve de Murville emphasized the importance of a firm, yet respectful defense of French interests as he stressed that frequent quarrels with US officials were to be expected (Documents Diplomatiques Français 1961, 63-68).

The disagreements that would later sour Franco-American relations were not yet present: neither differing views on NATO nor differences on the nuclear deterrent in Europe prevented healthy discussions between allied countries whose leaders shared mutual respect. Indeed, an inclination to accommodate and accept dissent permeated conversations from the early days of the Kennedy administration. In a meeting between President Kennedy and Ambassador Alphand on 10 February 1961, for instance, the American leader nonchalantly confessed that initial US positions on the Congo crisis were wrong-headed and that France had been vindicated by recent events (Documents Diplomatiques Français 1961, 60). Such an honest appraisal would have been unthinkable a mere two years later.

Franco-American differences over the policy to pursue in Indochina, however, had already emerged. Despite exhortations in favor of a "coordination of policies" by officials from both nations, disagreement on Southeast Asia was manifest, particularly with regards to the situation in Laos (Foreign Relations of the United States 1958, 225). Although both France and the United States agreed that a communist takeover of the country was undesirable, they diverged on the best means to beat back the violent insurgency. President Kennedy was reluctant to commit to a political solution: for him, the success of an international conference depended on a credible military threat that would force opposing parties to negotiate in good faith (Documents Diplomatiques Français 1961, 399-401). The French foreign affairs apparatus argued that a reconvened Geneva Conference involving the world's great powers would ensure the viability 
of a neutral Laos (Documents Diplomatiques Français 1961, 397-399). This foreshadowed the looming conflict over Vietnam, during which the French executive would make precisely the same suggestion.

The position of the French government was rooted in President de Gaulle's conviction that involvement in Southeast Asia by external forces was doomed to fail. In the Republic of Vietnam (RVN), recent events justified such skepticism. Relations with President Ngo Dinh Diem had precipitously worsened in the last weeks of 1960 as he became increasingly suspicious that American diplomats had had a hand in a recent coup attempt against him. US pressures for political reform of the regime exacerbated those tensions. To make matters worse, the National Liberation Front, a new communist insurgent organization, had recently been created and threatened the stability of the RVN (Miller 2013, 211 213). These concerning developments could not be obscured by Vice President Lyndon B. Johnson's visit to South Vietnam in May 1961. Days after the trip ended, French Ambassador to Saigon Roger Lalouette noted that "it would not be paradoxical to believe that Johnson's visit, rather than solve past problems [in Vietnamese-American relations], could be the cause of long-lasting and deep misunderstandings" (Documents Diplomatiques Français 1961, 641-645).

Ultimately, the French view was informed by the Republic's colonial history and the perception of adverse structural circumstances. Even if the RVN were stabilized and the Ngo brothers replaced with more efficient administrators, direct intervention in Southeast Asia would still risk disastrous consequences. In bilateral meetings during Kennedy's first visit to France in May and June 1961, de Gaulle stressed that the region was "a bad terrain militarily, politically and psychologically to fight a war" and that the chances of successful Western intervention had dimmed since the First Indochina War. France, he declared, would never again deploy troops in Indochina but "would not oppose" US involvement if it proved necessary (Foreign Relations of the United States 1961, 230).

During the three-day visit, differences of opinion were apparent but cordially expressed and diplomatically handled. In a conciliatory gesture toward Kennedy, for instance, the general agreed to keep his non-interventionist views private to foster uncertainty in the communist camp (Documents Diplomatiques Français 1961, 265). Though prepared to face significant opposition and to "combat" de Gaulle's views on Laos, the American leader concluded that the differences with France were of "secondary importance compared to the agreement:" the press, he triumphantly announced to US Congressmen days after his return, had blown disagreements out of proportion (Documents Diplomatiques Français 19611963, 22, 231). The US intelligence services, which had warned of the French president's "aversion to concessions," were also guilty of hyperbole (Digital National Security Archive 1961).
The genuine eagerness of both French and American officials to work out disagreements and maintain an appearance of collegiality is strikingly clear from the records of the early Kennedy administration. Both sides were cognizant of their differences. Nonetheless, high-level conversations were frank and substantively productive. Frustration had not yet set in; duplicitous behavior had not yet become the preferred diplomatic strategy. Moreover, the greatest areas of disagreement concerned Europe and the Soviet Union; Southeast Asia was not the original site of dispute which undermined Franco-American relations.

But while forbearing, the Kennedy administration was very much concerned with the so-called "problem of international opinion." As the situation in Vietnam stalled, the often naïve sense of renewal that enlivens a new government subsided and gave way to growing restlessness. "It would greatly improve our position," Johnson declared at a July 1961 meeting, "if the world could understand more clearly what in fact is happening there" (Foreign Relations of the United States 1961-1963, 109). In that regard, France was not yet a severe problem, but clearly it was not of great help either. It is possible that the American administration expected repeated prodding of de Gaulle to coerce him into adopting a position on Vietnam similar to that of the United States. However, in all likelihood, Kennedy's national security team was sworn in with a sincere intent to accommodate dissenting views from allies but grew impatient as success in Asia and elsewhere eluded them. The pressure was compounded by the failed Bay of Pigs invasion in April 1961, which drew widespread criticism and humiliated Kennedy (New York Times 1961).

In the fall of 1961 Franco-American relations manifestly worsened. Transatlantic discussions on NATO, nuclear arms, and communist insurgencies in Third World countries had barely progressed since the Kennedy inauguration. De Gaulle appeared intransigent and distant; his attention was, in fact, consumed with the ongoing crisis in Algeria. Frustrated, the Americans attempted to rationalize their continued commitment to friendly relations with France: Ambassador James Gavin noted that, regardless of his stubbornness, the French president was "a Western leader of proven sagacity whose councils can be of great value in our deliberations" (Foreign Relations of the United States 19611963, 236).

But with French officials increasingly voicing their disapproval of the strategy in Indochina, US officials grew impatient. Alarmed urgings replaced the conciliatory tone characteristic of early 1961. Speaking with Secretary Rusk on 13 November, Ambassador Alphand warned that "we fear that an American intervention in Vietnam would, instead of circumscribing the communist threat in Southeast Asia, precipitate a region-wide crisis" (Documents Diplomatiques Français 1961, 171). By the beginning of 1962, French and American officials were openly discussing the "unfortunate" tensions between their countries 
(Foreign Relations of the United States 1961-1963, 240). A 9 March 1962 telegram from Ambassador Gavin to Kennedy perfectly captures the situation: Gavin apologized for the long list of France-related quandaries he included in the memo but said it "emphasizes the magnitude of the problem" (Foreign Relations of the United States 1962, 242). By then, the press had caught on to the latest developments and, to the dismay of the American president, was exacerbating the problem by publishing inflated claims (Foreign Relations of the United States 1962, 248). Regardless of the media's tendency to hyperbole, the dynamics of Franco-American diplomacy were clearly changing: deteriorating relations were no longer an afterthought -they required immediate attention.

In this context, a meeting between Ambassador Gavin and President de Gaulle on 26 May rapidly lapsed into inflammatory and accusatory remarks. Discussing United States commitments abroad, de Gaulle implicitly faulted the superpower for its late intervention in both world wars. The discussion was abruptly ended by de Gaulle, which prompted Gavin to report that he had "never seen de Gaulle in more unfriendly and tense state of mind... [The] gap between our two governments is now farther apart than it has been in a long time" (Foreign Relations of the United States 1962, 252).

Despite boiling frustrations, there was still a willingness to cooperate and find mutually agreeable solutions. In October 1962, instructions addressed to Charles Bohlen, the new Ambassador to France, made clear that the United States' approach was to "seek the closest and most confident relations with France" regardless of the Republic's opposition to much of US foreign policy (Foreign Relations of the United States 1962, 260). To some extent, the Cuban Missile Crisis also helped mend ties. The imminent Soviet threat generated a warm "reaffirmation of solidarity and support" from de Gaulle (Digital National Security Archive 1962). Documentary evidence from October 1962 shows that de Gaulle acted as a supportive ally and was careful not to criticize unduly the American reaction. ${ }^{1}$

The first half of 1963 was characterized by an awkward, uneasy relation: numerous diplomatic reports mention that mutual incomprehension inhibited warmer ties. ${ }^{2}$ Asked what France, and de Gaulle more specifically, desired, French officials mechanically responded with "independence and alliance,"

1 See, for instance, "Dean Acheson's Meeting with Charles de Gaulle on Cuban Situation," 22 October 1962, Digital National Security Archive. Note that this interpretation is subject to debate. Fredrik Logevall has argued that the Cuban Missile Crisis reinforced de Gaulle's desire to pursue an independent foreign policy since it demonstrated that Europe could be drawn into a war it had not provoked. See Logevall, De Gaulle, Neutralization..., p.77-78. I have found little evidence supporting this claim in primary sources.

2 See, for instance, "Alphand à Couve de Murville," 16 February 1963, DDF 1963, Volume 1, Document 75 (pp.216-218). “Alphand au Ministère des Affaires Étrangères," 18 February 1963, $D D F$ 1963, Volume 1, Document 77 (pp.221-222). "Couve de Murville à Alphand," 19 February 1963, $D D F$ 1963, Volume 1, Document 78 (pp.223-225). as if a bland diplomatic platitude provided any additional clarity (Documents Diplomatiques Français 1963, 132, 384-385). But the tensions had not yet boiled over. In the summer of 1963, the situation would quickly spiral out of control.

\section{Simmering Tensions}

On 29 August 1963, roughly two years after Charles de Gaulle had begun to express private qualms regarding American involvement in Southeast Asia, the French President elected to publicize his views through his Minister of Information. The general's thinly-veiled criticism of the United States strategy in Vietnam triggered a bureaucratic frenzy in Washington; in the following months, American officials would question de Gaulle's motives for speaking out and ignore the substance of his proposal in the lead-up to the deployment of combat troops in the RVN.

While the symbolism of the August 29 statement was unmistakable, the plan's specifics did not hold up to careful scrutiny. Successful neutralization of Vietnam required a radical departure from recent Chinese behavior. Despite Vietnam's historical antipathy toward China, the Chinese and Vietnamese communist parties had developed an "intimate relationship" during the First Indochina War (Zhai 2000, 42). Whereas the Soviet Union under Khrushchev had embraced "peaceful coexistence," Chinese leader Mao Zedong remained committed to an activist foreign policy (Lüthi 2008, 161). His agenda was to "fight against the imperialists, revisionists, and reactionaries in all countries and, at the same time, to promote revolutionary developments at home and abroad." In fact, mere days after de Gaulle's 29 August declaration, Chinese Premier Zhou Enlai told Asian communist leaders assembled in Beijing that China would act as the "great rear" of revolutionary movements in the region (Chen 2010, 83, 208). De Gaulle's hope for a neutral Vietnam achieved through an international conference disregarded the reality on the ground. China was still an expansionary power and would remain so for much of the decade, which made neutralization unrealistic in the short-term. The agreement for the neutralization of Laos made in 1962 had already begun to unravel, which the French president conveniently ignored (Lüthi 2014, 117).

Regardless of the serious flaws that plagued the French proposal, the American reaction to public dissent was uncoordinated and unconvincing. In a meeting with Ambassador Alphand on 30 August 1963, Secretary Rusk argued that the United States government was not seeking a military solution in Vietnam but was forced to respond to repeated communist aggression of the RVN A neutralized Vietnam was an unrealistic solution given the continuing insurgency fueled by the leadership of the Democratic Republic of Vietnam (DRV) (Documents Diplomatiques Français 1963, 76, 214). Alphand conceded that Northern hostility made things more difficult; France "had no immediate 
solution" and "de Gaulle's statement was intended merely as a long term proposition, not as something that could be put into effect in the near future" (Foreign Relations of the United States 1963, 28). This, of course, was not immediately clear from the general's declaration and in the following months, American policymakers would consistently nag French officials to clarify this specific point.

The 30 August discussion offers a rare glimpse at candid diplomatic interactions between France and the United States following de Gaulle's remarks. Soon after, the American government's public relations machine began to churn out manufactured statements whose aim was to discredit the French president's opinion. The latter's proposal was never considered seriously; inasmuch as effort was expended to analyze the neutralization plan, it was with the intent of rejecting it more forcefully.

This uncompromising attitude is evident in a memo sent by national security adviser McGeorge Bundy to President Kennedy on 1 September. In his note, Bundy listed four possible responses to de Gaulle's declaration-none of which recommended giving serious thought to neutralization. Rather, the four options focused on two defamatory tactics. The first was to feign ignorance: "[w]e have noted the French statement, but we do not know just what it means." Failure to understand the proposal was improbable, particularly in light of the fact that the Kennedy administration had sponsored the 1962 Geneva Conference on Laos. The second tactic was to belittle France and downplay its role in Southeast Asia: "[a]s we understand this statement, it is simply a general expression of good will from a country which has no present responsibility in the area...Expressions of good will are always welcome.” Again, such a dismissive response was hardly justified by de Gaulle's declaration. For good measure, Bundy also personally derided de Gaulle: "we find only our own personal irritation as an argument against [the] well-established conclusion that we do best when we ignore Nosey Charlie" (Foreign Relations of the United States 1963, 43).

The memo, through its evocative wording and unyielding substance, is a window into the Kennedy administration's thinking. Though peculiarly combative, it set the tone for a ferocious campaign of French vilification. The conciliatory attitude of 1961-62 had definitively been abandoned. Public dissent on the issue of Vietnam would not be tolerated.

The American government's new approach was on display on 2 September when President Kennedy sat down for an interview with CBS anchor Walter Cronkite. Following Bundy's directives, the Commander-in-chief emphasized that the United States had been "carrying the burden" of liberty in Southeast Asia while France had done little. The president argued that it did no good to say "well, why don't we all just go home and leave the world to those who are our enemies" (New York Times 1963). This was of course a gross oversimplification of the French position, but the end goal was not to represent differing views accurately -it was to justify the existing Vietnam policy.

Meanwhile, Foreign Minister Couve de Murville continued to reassure allies that his president's proposal was a "long-term" solution (Documents Diplomatiques Français 1963 85, 232-245). The minister's prudent approach, however, was undermined by de Gaulle's sustained intransigence: the general refused to qualify his stance even as it became clear that Franco-American relations suffered as a result. In private conversations, the president of the Republic posed as a valiant truth-teller: "every country thinks like us, but some stand up while others stay quiet" (Documents Diplomatiques Français 1963, 122, 335-339).

By the beginning of October, the Kennedy administration had come to doubt the sincerity of de Gaulle's intentions: his proposal was not only unrealistic, but also motivated by blatant anti-Americanism. US officials believed that the French leader's decision to make public comments on Vietnam stemmed from his desire "to annoy the United States" after years of perceived inferiority (Foreign Relations of the United States 1963, 83). The Republic's president had not come to terms with his country's status as a junior partner in the post-war Western order and his childish reaction was to pester the superpower.

Admittedly, there was some truth to that assertion, but suspicion of ulterior motives does not grant one a license to disregard entirely the opinion of others. The French proposal, though partly inspired by a desire to reassert the country's foreign policy autonomy, was nonetheless worthy of consideration-if onlybecause US policy at the time was so visibly failing. By October 1963, the alliance with the ruling Ngo brothers had completely disintegrated and efforts to eradicate the National Liberation Front had only created more frustration. One would expect an administration confronted with such a bleak situation to be open to policy alternatives. Besides, there were other reasonable explanations for de Gaulle's inflexible beliefs on Third World nationalist movements. France's experiences in Indochina in the 1940s and 1950s and, the country's misadventures in Algeria had had a major effect on the general's thinking. Restoring France's status was only one of multiple competing explanations. Paradoxically, America's insistence that their ally's dissent was selfish was itself based on self-serving assumptions. By dismissing de Gaulle as "highly egocentric," the Kennedy administration could disregard his criticism and accuse him of injuring Western interests (Foreign Relations of the United States 1963, 277).

\section{Boiling over}

This image of de Gaulle as a self-absorbed leader would prove remarkably resilient. The French leader's intervention had come at a particularly unpropitious moment, when tensions between President Diem's government in 
the RVN and the United States reached unsustainable levels. Even assuming that de Gaulle was genuinely concerned about developments in Southeast Asia, the timing of his declaration was conspicuous (Documents Diplomatiques Français $1963,129)$, particularly given that just two years earlier he had promised not to publicize Franco-American disagreements on the Indochinese situation, as previously mentioned.

Once breached, confidence could hardly be repaired. De Gaulle was now considered one of three major threats to US global interests (Foreign Relations of the United States 1964,9). The perception that he "will accept any concessions or courtesies as a natural right and a recognition of his 'greatness"' made any semblance of conciliatory behavior disappear Foreign Relations of the United States 1963, 277).

France forewarned that the new military government in power after Diem's overthrow would escalate the war, demand increased assistance from the US, and alienate the South Vietnamese population. Though prescient, the warning went unheeded (Foreign Relations of the United States 1963, 297). Similarly, dissenting voices from within the US administration were marginalized or pressured to conform. A report David Nes, the Deputy Chief of Mission in Vietnam, notified the administration that "escalation may be the only alternative to inevitable neutralization" (Foreign Relations of the United States 1964, 52). Even such a clear statement from within the American government was ignored.

Tensions escalated further as France prepared for mutual recognition with the People's Republic of China (PRC) in January 1964. Though French officials insisted that the Asian nation's demographic weight made such a gesture necessary, American officials were alarmed: their allies had once again engaged in a dangerous course of action with the sole purpose of "showing independence" (Documents Diplomatiques Français 1964, 26). On 31 January, four days after the official recognition of the PRC, de Gaulle again publicly called for an international conference on, and neutralization of, Vietnam-this time with the added demand that China be involved (New York Times 1964). The proposal instantly stoked anxiety in Washington foreign policy circles regarding the effect it would have in South Vietnam (Foreign Relations of the United States 1964, 32).

If the media had exaggerated Franco-American tensions in the early days of Kennedy's presidency, the Johnson administration was guilty of exaggerating de Gaulle's hostility and overestimating his influence on world affairs. Renewed demands for neutralization triggered hysterical reactions from a broad spectrum of US decision-makers. Ambassador to Saigon, Henry Cabot Lodge warned of a "French neutralist plot" and counselled that "it is good tactics to start making a list of the things which he is doing which are against our vital interests. We can decide what use to make of the list later on" (Foreign Relations of the United
States 1964, 19). In an almost inconceivable turn of events, rumors of a "neutralist plot" forced Ambassador Alphand to assure Secretary Rusk that "France is not engaged in conspiracy in Southeast Asia against US effort" (Foreign Relations of the United States 1964, 63), McGeorge Bundy, for his part, recommended that the administration pressure key political figures favorable to de Gaulle's proposal to ensure that they kept quiet (Foreign Relations of the United States 1964, 39). President Johnson, in a remarkable act of willful blindness, continued to highlight that "the French have no plan or program" for Vietnam (Foreign Relations of the United States 1964, 107, 76, 84).

Throughout this period of early 1964, France's suggestions were never seriously considered. Notwithstanding the recognition of the PRC, the French position on neutralization was still naïve. Foreign Minister Couve de Murville himself had admitted that "the present situation has deteriorated so much that even the solution we have envisaged has only a small of succeeding" (Documents Diplomatiques Français 1964, 67). China was still an aggressive regional power, and the DRV did not seem intent on halting its support for armed struggle in the South. But regardless of the worthiness of alternative views, the mere presence of dissonant voices should have prompted administration officials to reconsider their approach. The war in Vietnam, after all, was fought on the basis of a purported need for credibility. The overriding concern was the reaction of allies around the globe should the United States be unable to defend them against blatant communist aggression (Logevall 1999, 388-389). Even the faintest signal indicating that involvement in a war halfway around the world was unnecessary should have been examined carefully. Regardless of his motives, Charles de Gaulle provided such a signal. Disagreement from a major ally should have made clear that American credibility did not hinge on the outcome of a conflict in a region that most Westerners knew little about. Instead, repeated warnings, both private and public, by the French over a period of several years yielded no change in United States policy. Obsessed with underlying motives, the Kennedy and Johnson administrations systematically rejected proposals that would have given them more room to maneuver. In short, the Americans had deceived themselves into believing their own theory of credibility.

\section{Conclusion}

On 2 April 1964, President Charles de Gaulle painstakingly clarified his views on the Vietnam situation to Ambassador Charles Bohlen. The United States, he argued, "could not possibly succeed" by continuing the policy it was currently pursuing. The Americans "would merely repeat the experience the French had earlier," which, as a loyal alliance partner, de Gaulle felt obliged to point out. The Vietnamese people "had no stomach for the war," and only an international conference resulting in neutralization could solve the Americans' dilemma 
(Foreign Relations of the United States 1964, 105). After months of complaints regarding the vagueness of France's proposal, the Johnson administration was finally delivered a clear, cogent explanation. Yet four months later, the United States president would use purported attacks against an American vessel in the Gulf of Tonkin as a pretext to seek congressional authorization to use all necessary means to combat the communist insurgency in Vietnam. Presented with an alternative and a way out, the United States doubled down.

The French plan for Vietnam, first expressed in May of 1961, was flawed: it suffered from a naively optimistic assessment of communist insurgency. The National Liberation Front, supported by the Democratic Republic of Vietnam, was deeply committed to protracted armed struggle. Additionally, China was devoted to supporting proletarian rebellions in Southeast Asia, with Vietnam being a focal point of this effort. A neutral Vietnam created in the early 1960s almost certainly would not have survived.

But the value of Charles de Gaulle's proposal lies not in its undisputable soundness, but rather in its symbolism. The French president's lonely dissent signified that another way was possible. From this point of view, the resulting increase in the bitterness of Franco-American relations is puzzling, for de Gaulle's outspokenness unshackled American decision-makers who felt trapped by the logic of credibility. The general's motives, however, appeared murky. What if public dissent was a mere façade designed to hide a much more selfish motive? Its sincerity being called into question, the proposal for a neutral Vietnam suddenly seemed self-serving.

Analyzing Franco-American relations in the lead-up to the escalation of the Vietnam War cannot elucidate the entire story, but in reexamining historical events, special attention should be given to those voices that proved prescient; in hindsight, de Gaulle's certainly was. This story of Franco-American tensions may seem like a mere historical curiosity. After all, the United States "won" the Cold War and the alliance of Western capitalist states proved to be much more cohesive than the Warsaw Pact of European communist countries. But willful blindness, misunderstanding, and self-induced pressure form the basic structure of international relations. States operate in a world of imperfect information in which motives are uncertain and long-term consequences are essentially unpredictable. A more complete narrative of the dispute over involvement in Southeast Asia does not magically solve the fundamental problems of world affairs. However, it highlights the inherent human biases which afflict decisionmakers, which helps to reduce the effect of those biases.
Digital National Security Archive

Documents Diplomatiques Français

Foreign Relations of the United States

\section{Secondary sources}

Bozo, Frederic. 2010. “France, 'Gaullism', and the Cold War.” In The Cambridge History of the Cold War, vol. 2, edited by Melvyn P. Leffler and Odd Arne Westad. Cambridge: Cambridge University Press.

Byrne, Jeffrey James. 2016. Mecca of Revolution: Algeria, Decolonization, and the Third World Order. New York: Oxford University Press.

Chen, Jian. 2010. Mao's China and the Cold War. Chapel Hill: University of North Carolina Press.

Costigliola, Frank. 1994. "Kennedy, De Gaulle, and the Challenge of Consultation." In De Gaulle and the United States: A Centennial Reappraisal, edited by Robert O. Paxton and Nicholas Wahl. Providence: Berg Publishers.

Costigliola, Frank. 1992. France and the United States: The Cold Alliance since World War II. New York: Twayne Publishers.

De Gaulle, Charles. 1954. Mémoires de Guerre, vol. 1. Paris: Plon.

De Gaulle, Charles. 1959. Mémoires de Guerre, vol. 3. Paris: Plon.

Gaddis, John Lewis. 2005. Strategies of Containment: A Critical Appraisal of American National Security Policy during the Cold War. New York: Oxford University Press.

Goscha, Christopher. 2016. The Penguin History of Modern Vietnam. Allen Lane: London.

Journoud, Pierre. 2011. De Gaulle et le Vietnam, 1945-1969 : la réconciliation. Paris : Éditions Tallandier.

Logevall, Fredrik. 1992. "De Gaulle, Neutralization, and American Involvement in Vietnam, 1963-1964." Pacific Historical Review 61:1.

Logevall, Fredrik. 1999. Choosing War: The Lost Chance for Peace and the Escalation of War in Vietnam. Berkeley: University of California Press.

Lüthi, Lorenz M. 2014. "Rearranging International Relations?: How Mao’s China and de Gaulle's France Recognized Each Other in 1963-1964.” Journal of Cold War Studies $16: 1$.

Lüthi, Lorenz M. 2008. The Sino-Soviet Split: Cold War in the Communist World Princeton: Princeton University Press.

McMaster, H.R. 1998. Dereliction of Duty: Lyndon Johnson, Robert McNamara, the Joint Chiefs of Staff, and the Lies that Led to Vietnam. New York: Harper Perennial.

Miller, Edward. 2013. Misalliance: Ngo Dinh Diem, the United States, and the Fate of South Vietnam. Cambridge: Harvard University Press.

Wall, Irwin. 2001. France, the United States, and the Algerian War. Berkeley: University of California Press.

Zhai, Qiang. 2000. China and the Vietnam Wars, 1950-1975. Chapel Hill: University of North Carolina Press.

\section{References}

\section{Primary Sources}

